\title{
HEREJÍAS Y DISIDENCIAS EN LA FRONTERA DE RIOVERDE: LOS BARRAGÁN EN EL SIGLO XVIII
}

POR

JOSÉ ALFREDO RANGEL SILVA

El Colegio de San Luis, San Luis Potosí, México

Gracias a los conocimientos adquiridos como bandido y arriero, el español Gabriel Fernández de Lima, alias Rufino Barragán, amasó una gran fortuna tras instalarse en Rioverde, una zona de guerra poblada desde finales del siglo XVII por hidalgos españoles. Sus opiniones heréticas y vida licenciosa fueron analizadas por la Inquisición, quien también tuvo problemas con su hijo y nieto. La documentación reunida en diversos archivos permite reconstruir la vida de los integrantes de una singular familia de pioneros en el Norte, conocida por sus manifestaciones poco ortodoxas.

Palabras clave: Frontera, élites, comercio, herejías, Septentrión Novohispano.

\section{INTRODUCCIÓN}

La zona de Rioverde, en el actual estado mexicano de San Luis Potosí, fue una frontera de guerra entre 1600 y 1770 aproximadamente. El espacio fue organizado por las misiones de una custodia franciscana y por los sitios y estancias otorgados por la Corona española; hacia 1700 comenzó una migración de españoles hidalgos a la zona en busca de fortuna, así como también de todo tipo de personajes en la ilegalidad. Uno de estos, Gabriel Fernández de Lima, alias Rufino Barragán, acumuló una considerable fortuna gracias a la usura, al comercio y a sus conocimientos como arriero y antiguo ladrón de caminos. Al mismo tiempo, destacó por una vida «licenciosa» y por expresar abiertamente una serie de opiniones heréticas que terminaron involucrándolo en un proceso inquisitorial. En un trabajo anterior mostré cómo en más de una manera Gabriel/Rufino fue una figura clave para la composición de las élites en la fronte- 
ra de Rioverde-Valle del Maíz en la segunda mitad del siglo XVIII'1 . Estableció las bases de la prosperidad que disfrutaron sus hijos por medio del comercio y de préstamos agiotistas, y representó el empuje de un grupo social en ascenso. A partir de unos mediocres inicios, como muchos otros españoles que llegaban para hacer las Américas y solamente engrosaban las filas de los vagabundos, desocupados y criminales ${ }^{2}$, Gabriel/Rufino supo sobreponerse a las adversidades y escaló la estructura social en una alejada zona de frontera.

$\mathrm{Su}$ hijo Felipe heredó sus bizarros puntos de vista y su riqueza. Felipe Barragán llegó a ser uno de los hombres más ricos de toda la Nueva España, además de mantener la herencia social de apellidos y vínculos de hidalguía de sus padres. El nieto de Gabriel, José Florencio, también mostró inclinación incorregible por expresar ideas religiosas y políticas incorrectas. Sin embargo, su poder económico le llevó a desempeñar, brevemente, un papel político relevante en el momento en que comenzaban los grandes cambios en los reinos españoles. La frontera les permitió prosperar y también vivir en los límites de lo posible en una sociedad que sospechaba de todo y denunciaba cualquier opinión extraña. Con base en expedientes inquisitoriales, este trabajo ubica las expresiones heréticas de los Barragán en el contexto ideológico de la época, como una rara mezcla de ideas protestantes y filosofías «libertinas». Mientras no dejaron la frontera, estas expresiones fueron controladas por la Inquisición, pero cuando el entorno político europeo y americano fue sacudido por las transformaciones de la época, ya no hubo fronteras de refugio para la diferencia y ya no se toleraron opiniones o actividades disidentes.

Según el Diccionario de autoridades de 1732, frontera era «La raya o término que parte y divide los reinos, por estar el uno frontero del otro» ${ }^{3}$, es decir, un límite territorial y político: la demarcación entre reinos que distingue y separa formas o jurisdicciones de gobierno. La frontera podía ser limítrofe, o bien ser interior: un área dentro de los dominios políticos de un reino donde había un escaso o nulo control y que, por tanto, permitía que sobrevivieran formas culturales distintas, como los grupos indígenas insumisos ${ }^{4}$. Rioverde fue una frontera interior, alejada de los límites con algún otro reino europeo,

1 Rangel, 37 (México, 2007): 123-166.

2 Véase Stern, 1998: 157-188.

3 Diccionario de Autoridades, 1969 [1732], vol. 3: 801.

4 Sobre la frontera limítrofe y la frontera interior, véase Lucena, 1996: 269. Las fronteras interiores eran zonas de difícil acceso, normalmente habitadas por grupos étnicos hostiles. La capacidad de resistencia de éstos residía en su organización política fragmentaria, su belicosidad y la dispersión de sus asentamientos. En el imperio español hubo varios casos. Lockhart y Schwartz, 1992: 237-255. Rangel, 2008: 19-24. 


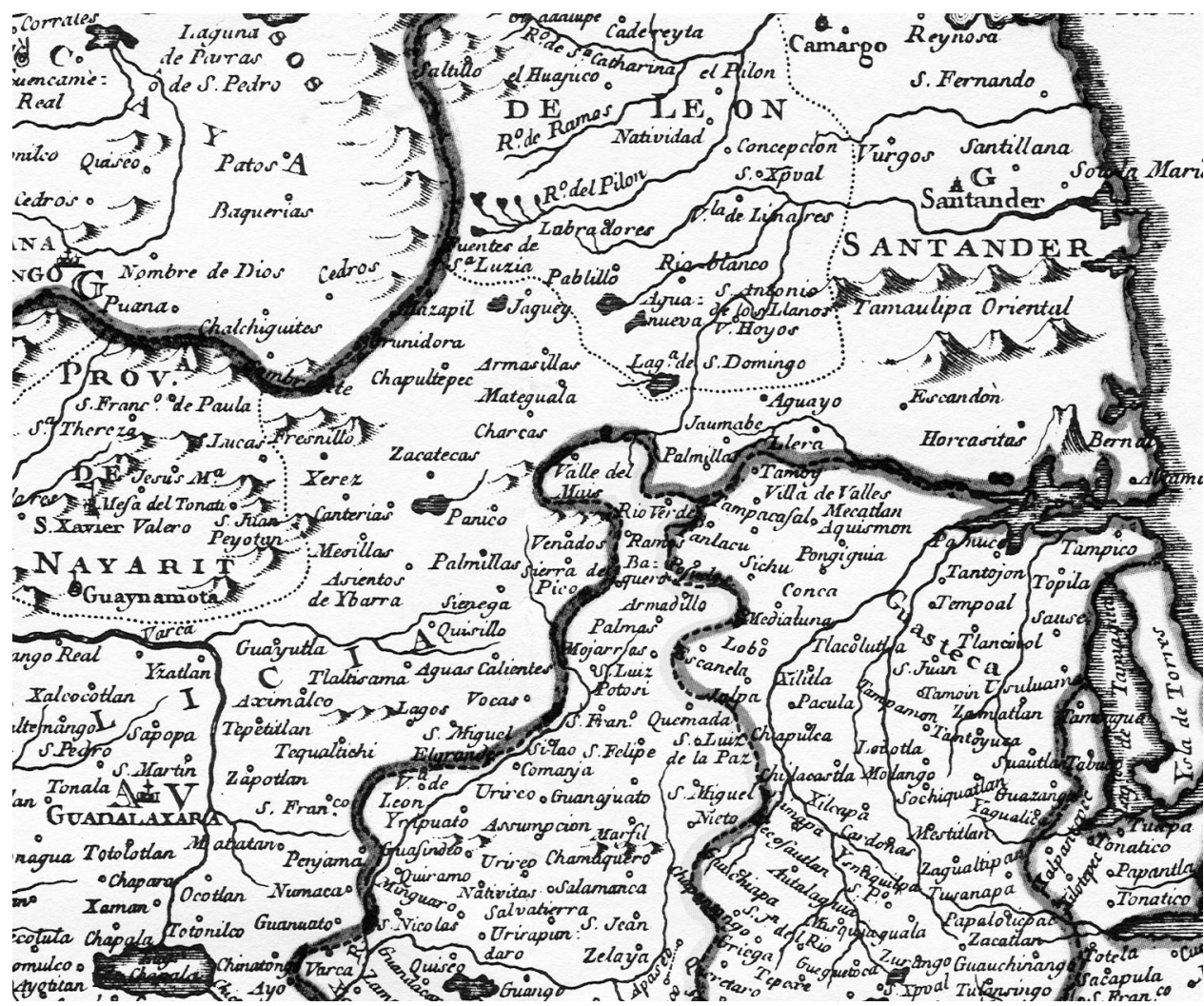

Fragmento del Nuevo Mapa Geográfico de la América Septentrional. José Antonio de Alzate. París, 1768.

pero representando el término del reino novohispano en el noreste. Era una zona remota, sin recursos económicos explotables en el corto plazo, y sometida a frecuentes incursiones de grupos chichimecas que resistían el dominio europeo $^{5}$. Sus dimensiones fueron imprecisas y en constante oscilación según el avance o retroceso de los intereses virreinales. Ahora bien, también fue un espacio de transición, interacción y conflictos entre grupos diferenciados: españoles, grupos chichimecas locales, indios ladinos, mestizos, negros y mulatos 6 .

5 Varias zonas en Nueva España fueron fronteras interiores. Una fue la sierra de Nayarit, ubicada entre los actuales estados mexicanos de Jalisco, Nayarit y Zacatecas. Péron, 1997: 43-76. Otra, las fronteras de Colotlán. Velázquez, 1961. Shadow, 2002: 57-60.

6 Al respecto, véase Weber, 1991; 2000: 28-30. Guillermo Céspedes del Castillo señala que la expansión española y portuguesa en América fue entendida como una prolongación de 
El resultado fue un orden distinto al que prevaleció en territorios ya conquistados. En medio de los procesos de disputa, los personajes de opiniones o estilos de vida heterodoxos, como los Barragán, encontraron un espacio de refugio y de oportunidades, e incluso lograron escalar la estructura social para alcanzar la hegemonía.

\section{DEL BANDIDO GABRIEL FERNÁNDEZ AL HEREJE «RUfINO BARRAGÁN»}

Gabriel Fernández de Lima del Castillo y Domínguez (su nombre completo) nació el 20 de mayo de 1693 en la villa de Corral de Almaguer, en La Mancha, reino de Castilla ${ }^{7}$. Su padre Juan Antonio Fernández de Lima y su abuelo Gaspar Fernández de Lima estaban registrados como hidalgos. Ambos eran «caballero noble hijodalgo notorio de sangre y naturaleza». Además, Gaspar fue regidor del ayuntamiento y alcalde ordinario del Corral de Almaguer entre 1671 y 1678 , y Juan Antonio regidor en $1703^{8}$. Gabriel/Rufino estuvo casado en España con Francisca Rodríguez y dejó varios hijos, según datos recopilados por la Inquisición 9 . Hasta aquí Gabriel fue simplemente un hidalgo más, una distinción que le separaba de los pecheros, que pagaban impuestos. No se sabe por qué razón salió para la Nueva España. Según los registros, era público que Gabriel se había «ausentado muy joven a los reinos de Indias» en compañía de uno de sus tíos, quien, según las fuentes, vino en servicio del rey, aunque no está claro ni el cargo ni el servicio ${ }^{10}$.

las fronteras del cristianismo de la Edad Media, por lo que la experiencia de la frontera era una condición incorporada en la cultura española, Céspedes, 1983. Sobre la experiencia de la frontera en la reconquista española, véase González, XVIII/69 (Zamora, 1997): 21-40.

7 José Florencio Fernández del Castillo, Barragán y Trejo, Jáuregui y Sáenz. Caballero. Valle del Maiz, Indias, 25 de septiembre de 1800, Archivo Histórico Nacional, Madrid (AHN), Estado, Orden de Carlos III, exp. 1120. José Florencio Barragán había recibido una cruz de la Orden en 1795, por ello solicitó este expediente, el más completo sobre la familia Fernández y Jáuregui Barragán. Véase también Cabrera, 1956: 42.

${ }^{8}$ La información sobre la hidalguía en José Florencio Fernández del Castillo, Barragán y Trejo, Jáuregui y Sáenz. Caballero. Valle del Maíz, Indias, 25 de septiembre de 1800, AHN, Estado, Orden de Carlos III, exp. 1120, ff. 78-91.

9 La información viene en el tomo acusatorio de los inquisidores. El señor inquisidor fiscal del Santo Oficio de México contra don Rufino Barragán, alias Gabriel del Castillo, por proposiciones, Año 1761. Archivo Histórico Manuel Castañeda Ramírez, Morelia (AHMCR), Fondo Diocesano, sección Justicia, siglo XVIII, exp. 58, caja 1238. Brading, 1994: 177, cita el caso como «pruebas fascinantes de una disidencia razonada» en el obispado de Michoacán.

10 Según el testamento de su madre, Leonor Domínguez Gutiérrez, quien además lo declaró como su único heredero, Gabriel viajó a las Indias desde antes de 1713. José Florencio Fer- 
No le fue muy bien a Gabriel/Rufino en sus primeros años en Nueva España, pues pronto comenzó a dedicarse a actividades ilícitas: una de las primeras fue fabricar y comerciar con «aguardientes falsos en las orillas de México». Ese negocio no era raro ni especialmente truculento, ya que mercaderes y hacendados lo hacían con cierta regularidad. Pero, como un pequeño productor, probablemente pronto enfrentó el fracaso. Aunque los detalles de las circunstancias son desconocidos, el siguiente paso registrado fue su participación en una cuadrilla de salteadores encabezada por «Juan Tomás, afamado ladrón de caminos». En esta época, Gabriel Fernández de Lima aparece como un hombre desesperado, llevado por las circunstancias a convertirse en un salteador. Como ya ha sido señalado por Hobsbawn, los desesperados rurales no eran campesinos por nacimiento ni por solidaridad, eran simplemente nobles arruinados convertidos en ladrones ${ }^{11}$. Como salteador, Gabriel estaba buscando una parte de las ganancias de una sociedad que le ofrecía pocas oportunidades legítimas para el progreso material personal, pero sin cuestionar el orden social. Su situación era un reflejo de su tiempo, pues en aquellos años el bandolerismo era un fenómeno común tanto en Andalucía y Castilla como en Nueva España ${ }^{12}$. Como a otros hidalgos en apuros, la vida no le había sonreído en Nueva España. Hasta ese momento estaba perdido en el anonimato de la mediocridad: un fracasado en la estructura social, no menos que en la económica, que luchaba por su supervivencia como mejor podía ${ }^{13}$.

Según sus detractores, en la cuadrilla de salteadores tuvo como compañeros de correrías a José Antonio Oyarbide, quien años después fue capitán en Horcasitas, una villa en la colonia del Nuevo Santander, y un tal Antonio Gar-

nández del Castillo, Barragán y Trejo, Jáuregui y Sáenz. Caballero. Valle del Maíz, Indias, 25 de septiembre de 1800, AHN, Estado, Orden de Carlos III, exp. 1120, ff. 87, 88.

11 La definición de bandido en Slatta, 1987: 1, que distingue al criminal del bandido social, que sería un campesino fuera de la ley considerado por sus compatriotas como un héroe o un vengador. Hobsbawn ya distinguía entre criminales y bandidos sociales. Hobsbawn, 1976: 9,10 .

12 Una interpretación sobre bandidos y salteadores en las postrimerías de la Nueva España y en el siglo XIX en México en Vanderwood, 1987: 13-26. Una perspectiva sobre el fenómeno en Andalucía en los siglos XVI y XVII en Domínguez Ortíz, 1989: 21-29. Para un periodo similar en Castilla, véase Guillaume-Alonso, 1989: 12. Para Sudamérica, Aguirre-Walker, 1990.

13 El problema novohispano de los peninsulares convertidos en criminales se puede revisar en Stern, 1998: 158, 159. Para un listado de personajes olvidados por la historia oficial, perdedores en el devenir histórico por vivir, pensar, hacer o expresarse de maneras heterodoxas: herejes, rebeldes, conspiradores, fronterizos, aventureros, etcétera, ver García Cárcel, 2005: 9-21. Las historiografías en Francia y España utilizan el término marginal para referirse a estos individuos fuera de las normas sociales y de las estructuras económicas, excluidos, desclasados, voluntariamente o por la fuerza de las circunstancias. Petit, 1995: 269-272. 
cía, quien supuestamente después fue corregidor en Santiago de los Valles, aunque esta información no se puede corroborar, y es parte de versiones distorsionadas y maliciosas (de 1760) sobre ese truculento pasado. De cualquier forma, los inquisidores fueron configurando un perfil criminal de sus robos, homicidios y prisiones, pues al parecer estuvo en prisión por sus actividades en los caminos ${ }^{14}$. El manchego logró huir de prisión y se dirigió a la Huasteca, zona que, desde el siglo XVI, refugiaba a personajes interesados en el anonimato ${ }^{15}$.

Gabriel ya vivía en los márgenes sociales como criminal; ahora literalmente viviría en la periferia, cerca de la frontera novohispana. Encontró un espacio en el pequeño pueblo de Coscatlán, en el corregimiento o alcaldía mayor de Valles ${ }^{16}$. Hubo dos razones para que saliera de allí: cometió un homicidio y, siendo hombre casado, sostuvo una relación adúltera con la criolla María Teresa de Jáuregui Barragán ${ }^{17}$. Criminal fugitivo, le era necesario el anonimato de la frontera, pero a este español parece que le era imposible quedarse tranquilo y terminó envuelto en la relación con María Teresa, de quien además tomó su apellido para llamarse Rufino Barragán ${ }^{18}$. La versión recopilada por la inquisición indica que tuvieron varios hijos sin desposarse, y que, cuando ella descubrió que era casado, lo denunció ante el cura local, por lo que Gabriel/Rufino huyó al Valle del Maíz, misión franciscana ubicada en los límites de la frontera de guerra, llevándose con él a sus hijos.

Desde la Edad Media, la cultura española había contemplado con cierta permisividad las cohabitaciones como el concubinato o barraganía, que se ca-

${ }^{14}$ El señor inquisidor fiscal del Santo Oficio de México contra don Rufino Barragán, alias Gabriel del Castillo, por proposiciones, 1761, AHMCR, Fondo Diocesano, sección Justicia, siglo XVIII, exp. 58, caja 1238, ff. 20v., 21, 26v. Dio la información el teniente del alcalde mayor en Valle del Maíz, Felipe Miguel de Andrada Moctezuma, y la ratificó el bachiller Ildefonso Álvarez Pereira. Oyarbide es mencionado como su paisano.

15 Por ejemplo, Santiago de los Valles y Pánuco albergaron en el siglo XVI a grupos de judíos portugueses conversos. Powell, 1997: 73.

16 En 1717 pidió a su padre que le enviará información sobre su limpieza de sangre y su hidalguía. José Florencio Fernández del Castillo, Barragán y Trejo, Jáuregui y Sáenz. Caballero. Valle del Maiz, Indias, 25 de septiembre de 1800, AHN, Estado, Orden de Carlos III, exp. 1120, f. 78. Para entender la frontera en la Huasteca y Rioverde, véase Rangel, 2008.

17 Para que cualquiera persona decente que sepa leer, y escribir, notifique al justicia del partido del Valle del Maíz, remita a esta capitanía general los autos que se expresan en el escrito inserto bajo la pena de quinientos pesos, año 1762, Archivo General de la Nación, México D.F. (AGN), General de parte, volumen. 43, exp. 342, f. 214.

18 Según su testamento, Gabriel/Rufino se casó con María Teresa de Jáuregui Barragán cuando ella estaba en artículo de muerte. Cabrera, 1956: 42, 43. Es incierta la veracidad del testamento, pues no fue usado en las pruebas de limpieza de sangre de su nieto José Florencio. 
racterizaban por la estabilidad y la permanencia ${ }^{19}$, así que la relación ilegítima que comenzaron Gabriel y María Teresa Jáuregui en ninguna manera era rara en la época, de hecho, las tasas de ilegitimidad eran diez veces más altas en Nueva España que en la península Ibérica ${ }^{20}$. Pero la permisividad no significaba una sanción legal o una aprobación social. Otros autores han mostrado que parte de la moral novohispana estaba inspirada en las Siete Partidas, la escolástica de Santo Tomás y las disposiciones del Concilio de Trento, donde la relación sexual entre un hombre y una mujer, antes o fuera del matrimonio, era un pecado, aunque menos grave o más tolerable que la homosexualidad por ejemplo ${ }^{21}$. Desde la óptica contemporánea queda la duda de si clasificar la relación extramarital como una desviación de las normas o como parte de la vida cotidiana en la Nueva España.

A pesar de su turbulento pasado, de sus deudas con la justicia y de haber llegado «desnudo» al Valle, Gabriel/Rufino aprovechó sus habilidades adquiridas para dedicarse al oficio de arriero, ámbito en que tenía amplios conocimientos y contactos por su experiencia como salteador de caminos. Aunque no es posible saber cómo ni cuándo, logró hacerse del cargo de justicia mayor en Valle del $\mathrm{Maí}^{22}$. Es probable que algunas de sus antiguas amistades, que también prosperaban en la frontera, le hayan ayudado a conseguirlo: colocarse todos en puestos de administración de justicia y poder político era una manera de asegurar que el pasado criminal quedara sepultado. El cambio de fortuna y su rápido ascenso económico llamaron la atención de sus coterráneos:

cuando vino huyendo de la Huasteca, vino desnudo, y aun se vio algunos años precisado a trajinar los caminos tras de unas mulas, y de seis años a esta parte, con un tendajón de un corto principal, ha sido el aumento de más de cien mil pesos de ganancia en reales, tiendas y casas, que tiene suspendido el juicio de los hombres ${ }^{23}$.

19 Por ejemplo, las Siete Partidas contemplaban una serie de restricciones y normas sobre la práctica extramarital. Sobre las relaciones fuera de matrimonio durante la Edad Media en Castilla, incluida la barraganía, véase Ratcliffe, 67/3 (Walled Lake Mi., 1984): 346-350. También Borah y Cook, 54/2 (Berkeley, 1966): 946-965.

${ }^{20}$ Los «tratos nupciales» en Nueva España incluían las múltiples formas de unión y de ayuntamiento sexual: Cohabitaciones, uniones de visita, emparejamientos esporádicos, concubinatos y barraganías. McCaa, 1996: 21-57. Barragán era, en algunos lugares de México, un «hijo de querida». Es interesante pensar en los posibles nexos entre la vida y costumbres de Gabriel Rufino y el significado del término.

21 Una interpretación de la moral novohispana en una villa fronteriza en Valdés, 1995: 51-57.

22 Cabrera, 1956: 42. Algunos testigos que patrocinó José Florencio Barragán también lo aseveraron. José Florencio Fernández del Castillo, Barragán y Trejo, Jáuregui y Sáenz. Caballero. Valle del Maiz, Indias, 25 de septiembre de 1800, AHN, Estado, Orden de Carlos III, exp. 1120, ff. 17-30.

23 El señor inquisidor fiscal del Santo Oficio de México contra don Rufino Barragán, 
Gabriel/Rufino se convirtió en el hombre más rico de aquella parte de la frontera mediante el comercio, «vendiendo por tres lo que compra por uno», aunque el ingreso principal parece haber sido por la fabricación y venta de aguardiente o chinguirito. De hecho, fue acusado por algunos de sus vecinos de desobedecer una censura del obispo de Michoacán contra las bebidas prohibidas, pues cuando la mayoría de los comerciantes obedeció al prelado y tiró el aguardiente que poseía, Gabriel/Rufino desacató la orden y aprovechó la consecuente escasez para disfrutar una ventaja monopólica en la venta de la bebida, elevando el precio del «cuartillo» de tres reales a seis, «y no cesó de venderlo por adelantar su caudal». Lo que escandalizó a la Inquisición fue que, según los vecinos, Gabriel/Rufino dijo públicamente que la censura era pura palabrería para aterrorizar a la gente y «que el señor obispo era un patarato», $y$, aunque no lo hubiera dicho, sus acciones dejaron ver la poca importancia que dio al decreto episcopal. Su bonanza terminó cuando "dos jueces comisarios» de la capital virreinal le confiscaron diez barriles de aguardiente de piloncillo y lo encarcelaron. Salió de la cárcel, pero el proceso legal por su desacato continuó hasta 1761 en la ciudad de México ${ }^{24}$.

Por otro lado, el nativo de La Mancha no contuvo su inclinación por las relaciones extramaritales al tener varias mujeres «en públicos duplicados concubinatos». Una vez más, lo peor, en la mirada de vecinos e inquisidores, no era el amancebamiento, sino el escándalo con el que se conducía al hacer alarde de su situación, «manteniendo las mancebas en su propia casa con las mismas demostraciones, trato y libertad que si fuesen sus mujeres legítimas, cuidando los hijos que de ellas ha tenido en los mismos términos que si fuesen de legítimo matrimonio» ${ }^{25}$. Puede uno imaginarse a Gabriel/Rufino como un patriarca rodeado de sus mujeres y sus hijos, o como una figura autoritaria, machista y arbitraria, como posiblemente él mismo deseaba ser visto. Una vez más, el

alias Gabriel del Castillo, por proposiciones, 1761, AHMCR, Fondo Diocesano, sección Justicia, siglo XVIII, exp. 58, caja 1238, f. 27. Ildefonso Álvarez Pereira era bachiller, teniente de cura y juez eclesiástico sustituto en el real de Guadalcazar.

24 Idem. Otra fuente de su fortuna vino de los préstamos agiotistas a hacendados y a cualquiera que tuviese propiedades con que respaldarse. Por ejemplo, en 1754, un decreto del virrey primer conde de Revilla Gigedo le prohibió, por un periodo de seis meses y bajo pena de 200 pesos, exigir a Juan Basilio de Azua, dueño de la hacienda Gallinas, el pago de la deuda por 615 pesos que tenía con él: V. e. concede a Juan Basilio de Azua dueño de la hacienda nombrada Las Gallinas, en jurisdicción de San Luis Potosi la moratoria de seis meses, para paga de sus créditos, julio de 1754, AGN, General de parte, volumen 40, exp. 12, f. 28r-28v.

25 El señor inquisidor fiscal del Santo Oficio de México contra don Rufino Barragán, alias Gabriel del Castillo, por proposiciones, 1761, AHMCR, Fondo Diocesano, sección Justicia, siglo XVIII, exp. 58, caja 1238, f. 4. 
caso de los múltiples concubinatos no fue único; otros investigadores han mostrado cómo este tipo de conducta era parte de las formas sociales novohispanas, sobre todo en regiones aisladas, lejos de la capital virreinal y, por ello, con un débil control institucional ${ }^{26}$. Pero ese comportamiento no fue privativo de regiones de frontera: adulterio, amancebamiento y fornicación eran expresiones comunes de la relación hombre-mujer, y la opinión de que no eran pecaminosas, por lo menos no de forma mortal, estaba muy extendida. Rufino era uno de los que opinaban así, de hecho, proferirlo a oídos de otros fue lo que dio pie a la investigación inquisitorial:

autos y causa tuvieron principio por la denuncia que contra el expresado hizo por medio de carta misiva [...] don José Antonio Ortiz de Zárate [...] vecino del mencionado pueblo del Valle del Maíz, por haberle oído y entendido proferir, y persuadir la proposición de que el sexto mandamiento está mal entendido, pues no se le debe dar la inteligencia común que le dan los fieles, porque en esta palabra no fornicarás, no es prohibido a los hombres el uso de las mujeres, sino que solo se da a entender no inculcar la ley, ni ser transgresores de ella ${ }^{27}$.

El amancebamiento no era un grave problema mientras el culpable no intentara justificarlo, pues todos lo entendían como transitorio; pero una vez que se hacía referencia al ámbito teológico, se daba pie a la intervención de las autoridades eclesiásticas. En la acusación se decía que Gabriel/Rufino promovía esta forma de vida entre sus hijos, a quienes permitía sus propios amancebamientos y concubinatos, dando además un espacio a sus concubinas en su propia casa, «complaciéndose y regocijándose en estos mismos desórdenes, y disoluciones de sus hijos, criando y tratando a los que estos han tenido de sus ilícitos concubinatos como a sus nietos, enseñándoles a todos los vecinos con la denominación de tales». Sus hijos fueron excelentes discípulos, pues se decía que ellos: «han quitado su virginidad a varias niñas doncellas, con el engaño de palabra de casamiento, dejándolas con hijos, y por el respeto y caudal de dicho don Rufino, no han tenido aliento los padres ofendidos a demandar el daño recibido ${ }^{28}$. Para la moral novohispana, el honor personal y familiar esta-

26 Alberro, 1991: 155-166. Valdés, 1995: 53.

27 El señor inquisidor fiscal del Santo Oficio de México contra don Rufino Barragán, alias Gabriel del Castillo, por proposiciones, 1761, AHMCR, Fondo Diocesano, sección Justicia, siglo XVIII, exp. 58, caja 1238, f. 2 (Subrayado en el original). Casos de opiniones similares castigadas por la inquisición en Medina, 1991. También en Penyak, 1993: 46-49.

${ }^{28}$ El señor inquisidor fiscal del Santo Oficio de México contra don Rufino Barragán, alias Gabriel del Castillo, por proposiciones, Año 1761, AHMCR, Fondo Diocesano, sección Justicia, siglo XVIII, exp. 58, caja 1238, ff. 20-27. Para ejemplos en otros reinos americanos, McCaa, 1996: 42, 43. Para una perspectiva sobre estas costumbres en el siglo XIX, Dysart, 7/4 (Logan U., 1976): 365-375. 
ba ligado a la legitimidad o a su carencia, de manera que la barraganía multitudinaria como norma de vida, y no como una situación transitoria, atentaba contra el orden social y sus fundamentos morales. No obstante, mientras no hubo denuncias, los Barragán no dejaron de practicar los amancebamientos. Incluso al final de su vida, Gabriel/Rufino vivía con una indígena viuda, relación que había iniciado cuando ella era casada. Al parecer tuvo tres hijos con ella.

Pero en medio de los chismes y alborotos sobre sus desordenadas costumbres ${ }^{29}$, Gabriel/Rufino finalmente se casó con María Teresa de Jáuregui, a quien debió traer de la Huasteca. El matrimonio fue registrado en una partida en el archivo parroquial del Valle:

casé y velé [...] a don Gabriel Fernández de Lima español originario de los reinos de Castilla en el lugar de Almaguer de La Mancha, viudo de doña Francisca Rodríguez y justicia mayor de esta dicha misión, con doña María Teresa Jáuregui española, natural de Alaquines, vecina de Coscatlán, y residente en esta referida misión ${ }^{30}$.

María Teresa, nacida en la misión de Alaquines, era hija de Nicolás Jáuregui y de Ana Barragán ${ }^{31}$. No está claro en qué momento decidió seguir a nuestro bizarro personaje, pero, cuando se casaron, él ya era viudo según el fraile que los unió en enero de 1735, aunque ya estaban juntos en Valle del Maíz desde mediados de 1732, por lo menos, cuando ella tenía 25 años de edad y Gabriel/Rufino contaba con 39 años. Es decir, que fue durante su matrimonio con el manchego cuando sostuvieron las mencionadas relaciones ilegítimas con los consecuentes hijos «naturales». En el mundo novohispano no era raro que una mujer cediera a los galanteos de un varón sólo con la promesa de esponsales como garantía. Aparte de que los esponsales tenían reconocimiento jurídico, para una criolla había mucha competencia en la «feria nupcial» novohispana por parte de las concubinas mestizas, negras e indígenas, aunque ser una mujer blanca ciertamente le daba ventaja. El problema era que había más mujeres que hombres: en el grupo criollo-español la proporción era de diez a una aproximadamente ${ }^{32}$. Así, aunque Gabriel/Rufino no era un dechado de

29 El señor inquisidor fiscal del Santo Oficio de México contra don Rufino Barragán, alias Gabriel del Castillo, por proposiciones, Años 1761-1762, AHMCR, Fondo Diocesano, sección Justicia, siglo XVIII, exp. 58, caja 1238, ff. 20-22v, 26-27.

30 José Florencio Fernández del Castillo, Barragán y Trejo, Jáuregui y Sáenz. Caballero. Valle del Maiz, Indias, 25 de septiembre de 1800, AHN, Estado, Orden de Carlos III, exp. 1120 , f. 39.

31 Primera copia testimoniada, autorizada, y comprobada de la información de legitimidad y limpieza de sangre del capitán don José Florencio Fernández del Castillo, Jáuregui y Barragán, Trejo, Sáenz, y Torres, 1793, AGN, Vínculos y mayorazgos, volumen 282, exp. 2, f. 11.

32 McCaa, 1996: 39-47. El concepto «feria nupcial» es suyo. 
virtudes, sí era una opción matrimonial para una criolla; él y María Teresa compaginaban en compartir calidades y antecedentes familiares de hidalguías. Por supuesto que, una vez casados, Gabriel/Rufino nunca dejó su estilo de vida desordenado. Así que, para salvaguardar su honor y dejar en claro su descendencia, María Teresa declaró en su testamento:

estar casada y velada in faciae eclesiae [...] con don Gabriel Fernández de Lima, y que durante nuestro matrimonio, tuvimos por nuestros legítimos hijos a don Felipe Santiago y a doña Juana Fernández de Lima y Barragán, a quienes declaro por tales para que conste ${ }^{33}$.

La declaración de una mujer cuyo carácter debió de ser estoico es contundente en este punto. Reconoció a Felipe Santiago y a Juana Fernández de Lima y Barragán como sus únicos hijos y herederos. Aunque en el mismo 1753 Gabriel/Rufino asentó en su propio testamento que otros hijos suyos - Antonio Miguel y José Amaranto- también eran de María Teresa, lo redactó después de que ella hiciera el suyo.

Como personaje, Gabriel/Rufino destacó en muchos sentidos. Su descripción, hecha en 1761 por un comisario de la inquisición poco antes de su muerte, resalta la interesante personalidad que debió tener:

hombre bien apersonado, como de cien años de edad, ha sido de robusta naturaleza, bajo de cuerpo, peso doblado, de arrogante corazón, trágico, noticioso y muy capaz, pues sin haber cursado estudios habla latinidad, y con destreza discierne y maneja pronto textos sagrados, y autoridades de santos padres, muy inclinado a mover cuestiones morales, por lo que se hace muy atractiva y deleitable su conversación ${ }^{34}$.

En los años finales de su vida era el personaje más destacado en Valle del Maíz y, aunque no tenía amigos, su casa y su tienda eran puntos obligados de reunión de los criollos y peninsulares que se preciaban de ser alguien: «con el motivo de conversar, por ser hombre muy leído, con cuya ocasión se juntan varios vecinos en su tienda a divertir los ratos ociosos». Claramente admirado, era igualmente despreciado, en especial por los miembros de la élite como Felipe Miguel de Andrada, quien dijo que Rufino era en sus pláticas «angelical profundo, y generalmente noticioso», pero detrás de la fachada había un

33 José Florencio Fernández del Castillo, Barragán y Trejo, Jáuregui y Sáenz. Caballero. Valle del Maiz, Indias, 25 de septiembre de 1800, AHN, Estado, Orden de Carlos III, exp. 1120, ff. 101, 102. El testamento se fechó en 1753. Los antecedentes de hidalguía de la familia de María Teresa en las ff. 92-98, 159-163.

34 El señor inquisidor fiscal del Santo Oficio de México contra don Rufino Barragán, alias Gabriel del Castillo, por proposiciones, 1761, AHMCR, Fondo Diocesano, sección Justicia, siglo XVIII, exp. 58, caja 1238, f. 26. 
hombre que no dudaba en «proferir temerarias maldiciones». Y casi todos le temían:

Y siendo como es, el mencionado don Rufino Barragán [...] por su caudal tiene sujeta la voluntad de todos, y consecuentemente a su imitación y ejemplo se han de precipitar al estrago de los vicios con irreparable destrozo de sus almas, y ultraje de nuestra santa $\mathrm{fe}^{35}$.

Fue justo en los últimos dos años de su vida cuando finalmente fue denunciado ante la Inquisición novohispana por proposiciones heréticas por José Antonio Ortiz de Zárate, quien aseguró hacerlo guiado por su celo religioso. Los comisarios de la Inquisición en Guadalcazar fueron enviados a realizar las pesquisas. Ortiz de Zárate y otros testigos ratificaron la denuncia, añadiéndose como agravantes los múltiples concubinatos y adulterios ya mencionados. Pruebas irrefutables, según los inquisidores, de que practicaba lo que predica$\mathrm{ba}^{36}$. El eje de la denuncia era la negación en público de la aparición de la guadalupana:

enseñándole al que declara una hermosa lámina de la Purísima Concepción esculpida sobre un campo de estrellas: alabando el que declara su hermosura, le dijo que aquella era la imagen que decían se le había aparecido a Juan Diego en el santuario de Nuestra Señora de Guadalupe, dudando y dando a entender que no era cierta su maravillosa aparición. Sin advertir este mal cristiano que [...] la purísima concepción estar de otro modo, y distintamente vestida ${ }^{37}$.

Se desliza en la acusación la sugerencia de que ese mal cristiano no podía distinguir entre las imágenes mencionadas, algo que cualquier católico haría fácilmente. En opinión de los vecinos que lo denunciaron, era un «hombre tan inicuo» que no se le conocía ninguna acción cristina, ni el menor afecto al santo rosario. Sus detractores le achacaron la frase de que no había ningún santo en el cielo más santo que su hijo Felipe. El colmo fue que en su testamento no pidió misas por el descanso de su alma. Gabriel/Rufino tenía 68 años de edad y se encontraba en México para resolver el proceso legal por el embargo del chinguirito, así que los inquisidores se dieron prisa en la investigación, porque podría «desfallecer el celo del denunciante, y testigos». Estos eran parte de la élite local y sus rivales o enemigos: el capitán de milicias Ortiz de Zárate, el sargento Sáenz y el terrateniente Andrada Moctezuma, personajes que habían dominado la sociedad y la economía hasta que el antiguo salteador acumuló su

35 El señor inquisidor fiscal del Santo Oficio de México contra don Rufino Barragán, alias Gabriel del Castillo, por proposiciones, 1761, AHMCR, Fondo Diocesano, sección Justicia, siglo XVIII, exp. 58, caja 1238, f. 2-9v.

36 Idem.

37 Idem. 
fortuna. Aprovecharon su ausencia y sus problemas legales por el aguardiente para tratar de asestarle un golpe definitivo. Pero cuando el fiscal pidió que el comerciante fuera declarado reo de la Inquisición, enviado a las «cárceles secretas» por hereje y el embargo de sus bienes, libros y papeles, en enero de $1762^{38}$, Gabriel/Rufino había muerto. Falleció el 30 de diciembre de 1761 a consecuencia de un accidente en el camino de regreso al Valle. Un inquisidor describió con menosprecio el testamento de Rufino así como sus momentos finales:

aun estando enfermo de muerte, es su cama un pobre colchoncillo prestado, las sábanas unos trapos de Rúan, y por colcha un cuero de cíbolo. Su curación ninguna, y su alimento el común y muy escaso, Su disposición testamentaria, lastimosísima, porque sus cláusulas son estas: ochocientos pesos le señala a José que es el menor, a Antonio Miguel nada, y a Felipe toda la gruesa del caudal. Su entierro pobre y en el cementerio, sin acordarse de obra pía [...] ni hacer por su pobre alma en siquiera una misa. Cuya vida y presentes hechos, desde el principio hasta el fin, ha puesto al vulgo en el estrecho de tener por evidente que no es cristiano, y que su alma es de una de las eternamente infelices ${ }^{39}$.

Hasta en su muerte estuvo rodeado de celos, chismes y sospechas del «vulgo» y de la élite local. Se dijo que no dejaron enterrar su cuerpo en la iglesia de la misión, y que la Inquisición había dado órdenes de que, alrededor de su tumba, a las afueras del pueblo, no se enterrase ningún otro cadáver. La infelicidad eterna le fue impuesta por sus vecinos terrenales. ¿Por qué razón la Inquisición no siguió con el proceso? Hacerlo no habría sido extraño; pero los tiempos eran diferentes, ya que el tribunal no tenía ni la misma fuerza ni la misma convicción para cumplir sus tareas. Lo importante era que, con el proceso seguido, se logró controlar la propagación de las ideas heréticas en la frontera. Si el poderoso Rufino Barragán estuvo muy cerca de ser condenado, ¿qué podría esperar un hereje de menor capacidad económica?

\section{HERENCIA Y HETERODOXIA DE FELIPE BARRAGÁN}

Desde joven, Felipe se empeñó en aprender al detalle el oficio y aprovechar el consejo experimentado de su padre en el negocio familiar ${ }^{40}$. Aparente-

38 Idem.

39 El señor inquisidor fiscal del Santo Oficio de México contra don Rufino Barragán, alias Gabriel del Castillo, por proposiciones, 1761, AHMCR, Fondo Diocesano, sección Justicia, siglo XVIII, exp. 58, caja 1238, f. 27v.

40 Autos seguidos por los naturales del Valle del Maíz de la jurisdicción de Villa de Valles con los vecinos españoles y la casa mortuoria de don Felipe Barragán sobre tierras, 1800, AGN, Tierras, volumen 1325, exp. 1, f. 18v. 
mente, al principio no hubo provecho en enseñar a Antonio Miguel los gajes del oficio, o por lo menos esa fue la versión de Felipe ante las autoridades virreinales y ante quien pudiera ${ }^{41}$. Esto coadyuvó a la marcada preferencia que Gabriel/Rufino tuvo por Felipe, el hijo legítimo que perpetuaba los linajes materno y paterno. En el expediente inquisitorial se aseguró que el peninsular prácticamente idolatraba a su hijo «Felipe, en quien solo tiene el cuidado y el amor» ${ }^{42}$. El afecto llegó a tanto que, cuando Felipe asesinó a un parroquiano en una riña bajo los efectos del alcohol, el padre no hizo más que alabarlo según los vecinos: «dame hijo esas manos te las besaré por la muerte que has dado a ese pícaro ${ }^{43}$. Pero es probable que lo que realmente distanció a los medios hermanos fue la disposición testamentaria de Gabriel/Rufino. Por ley, un hijo «natural» como Antonio Miguel no podía tener derecho a la herencia paterna, aunque el padre podía darles algo en vida. Solo un hijo legítimo, como era el caso de Felipe, podía ser heredero legal. Así que, cuando el padre no dejó dinero para sus hijos ilegítimos, provocó enconos, envidias y otros sentimientos negativos contra aquél.

Según Felipe, su hermano quería parte de los bienes que él había adquirido «a costa de mi sudor y trabajo», pero se negó a darle ni un real más ${ }^{44}$. Entonces Antonio no sólo lo maldijo, sino que lo amenazó con delatarlo ante la Inquisición por ciertos libros que tenía. El pleito familiar se complicó porque sus enemigos pensaron que era el momento propicio para atacarle. Lo acusaron de herejía:

estando parlando con un vecino [...] en su tienda de mercadería sobre los israelitas llegué yo que serían a las siete de la noche y estando en esta parla la prosiguió conmigo estando presente el otro y me dijo por mas grande duda de que Cristo Señor Nuestro y Dios hombre bajase a las impuras manos de los sacerdotes que él dudaba era esto porque si los israelitas huían de Moisés cuando les manifestaba las tablas

41 Testamento de Felipe Barragán, 1796, AGN, Tierras, volumen 1325, exp. 1, f. $134 \mathrm{r}-134 \mathrm{v}$.

${ }^{42}$ El señor inquisidor fiscal del Santo Oficio de México contra don Rufino Barragán, alias Gabriel del Castillo, por proposiciones, 1761, AHMCR, Fondo Diocesano, sección Justicia, siglo XVIII, exp. 58, caja 1238, f. 21.

43 El señor inquisidor fiscal del Santo Oficio de México contra don Rufino Barragán, alias Gabriel del Castillo, por proposiciones, 1761, AHMCR, Fondo Diocesano, sección Justicia, siglo XVIII, exp. 58, caja 1238, f. 12. Se siguió un proceso judicial y Felipe fue desterrado de Villa de Valles por un año, al demostrarse que Lobato no murió por las heridas de aquella noche. Para que cualquiera persona decente que sepa leer, y escribir, notifique al justicia del partido del Valle del Maíz, remita a esta capitanía general los autos que se expresan en el escrito inserto bajo la pena de quinientos pesos, 1762, AGN, General de parte, volumen 43, exp. 342, ff. 213v, 214.

\section{Idem.}


de la ley, por el resplandor que de estas salía, sin tener más que el estar escritas por mano del mismo Dios, que qué fuera si este mismo Dios bajara. Y que nuestra ley estaba adulterada, porque en el viaje que echó a México había oído decir que estaban unas religiones escribiendo en contra nuestra ley en los Reinos de Castilla, y que nuestra señora de Guadalupe no fue cierta su aparición pues eso lo habian introducido para la mejor conquista de los indios ${ }^{45}$.

Hizo la denuncia Máximo de Otero, quien había estado como aprendiz en el negocio de Felipe. Cualquiera, incluida por supuesto la Inquisición, podría captar las ideas protestantes en boca del heredero Barragán: ya no había sutileza en la acusación. Durante las pesquisas, los testigos resaltaron los aspectos protestantes de la denuncia, como que Felipe renegara del diezmo «por ser impuesto por la criatura, y no por Dios», e insistieron en la idea de que el fallecido Gabriel/Rufino poseía libros «prohibidos». Ahora bien, a la distancia, no parece que los Barragán fueran simpatizantes de los credos protestantes (su manera de vivir desmentía cualquier sospecha de protestantismo). Es más probable que buena parte de lo que decía proviniese de ideas heterodoxas. Una frase atribuida a Felipe es reveladora en este sentido: «creo que hay Dios, porque alguno había de haber que formara este universo, pero en lo demás, aquí cerró los labios» ${ }^{46}$. Este no parece un credo protestante, sino una declaración que, por su generalidad, indica otro tipo de ideas más filosóficas que religiosas, parecidas a las de los «libertinos», pensadores europeos en la Europa de la Reforma y la Contrarreforma que abrigaron opiniones radicales y consideraron la religión como una invención humana que mantenía a los estratos inferiores sometidos y obedientes ${ }^{47}$. Ateos, descreídos, deístas, muchos fueron los nombres dados a estos individuos que sencillamente pensaban y se expresaban de forma diferente sobre la verdad aceptada por las mayorías. Pero no importaba si era protestante o «libertino», para la Inquisición sería un hereje, aunque para su fortuna los tiempos más eficaces y decididos del tribunal ya habían pasado $^{48}$. Felipe, entonces de 28 años, era tan odiado por los vecinos como lo había sido su padre. Le tenían por:

hombre poco aplicado a todo ejercicio de virtud, muy presuntuoso de literato, usurero, avariento, intrépido en destrozar (sin excepción) los créditos ajenos, adúltero,

45 Don Felipe Barragán, vecino y mercader en el Valle del Maíz, por proposiciones, 1762, AHMCR, Fondo Diocesano, sección Justicia, siglo XVIII, exp. 60, caja 1238, ff. 3-4 (Subrayado en el original).

46 Don Felipe Barragán, vecino y mercader en el Valle del Maíz, por proposiciones, 1762, AHMCR, Fondo Diocesano, sección Justicia, siglo XVIII, exp. 60, caja 1238, ff. 14-16.

47 Tenenti, 1999: 231-245. Menéndez Pelayo, 1951, vol. V: 275-286.

48 En esto coinciden los diversos autores que han trabajo el tribunal inquisitorial. Medina, 1991: 453-475. Pérez-Merchand, 2005: 109-118. 
homicida y bullicioso. Acciones todas que le han privado la estimación de estas comarcas, pues no se oye una palabra a favor de sus hechos ${ }^{49}$.

Felipe carecía de la atractiva personalidad de su padre, aunque había seguido su ejemplo en su desordenada manera de vivir. La herencia del padre incluía las envidias e intrigas de los vecinos, sobre todo de los competidores y rivales en el ámbito mercantil, pues sus acusadores eran comerciantes del Valle del Maíz: Máximo Otero, aprendiz y empleado en la tienda de los Barragán, era el principal acusador, además de Francisco y Fernando Morales, que tenían una tienda. Es probable que este grupo esperara que, con la caída de Felipe, desapareciera el principal comerciante regional. También participaba, otra vez, José Antonio Ortiz de Zárate, el capitán y protector de los indios pames ${ }^{50}$. Además se involucraron dos frailes franciscanos: Antonio Salceda y Francisco Núñez. La clave de la acusación era que Antonio Miguel formalizara su denuncia sobre los supuestos libros prohibidos que poseía Felipe, y que habían sido de Gabriel/Rufino ${ }^{51}$.

Al mismo tiempo, la animadversión entre los hermanos impulsó a Antonio a apoyarse en el nuevo justicia de Valle del Maíz, Joaquín Manuel Pérez Correa, para obligar a Felipe a ceder en la repartición de bienes, o por lo menos a que le diese una cantidad sustancial:

ofreciéndole [al justicia] tres mil pesos para que a mi parte le obligasen a dar ocho, más como se resistiese a tan inicua petición, arrestaron su persona en su propia casa, poniéndole muchas personas que la guardasen, y obligándole a dar cuatro reales a cada una y como viesen que ni aun esto le obligaba a conceder en tan injusta y desarreglada pretensión, trataron de conducirlo para la cárcel pública, para ver si el más riguroso apremio acababa de quebrantar su voluntad y mediante él lograba cumplir sus deseos ${ }^{52}$.

49 Don Felipe Barragán, vecino y mercader en el Valle del Maiz, por proposiciones, 1762, AHMCR, Fondo Diocesano, sección Justicia, siglo XVIII, exp. 60, caja 1238, f. 8v.

50 A diferencia de la acusación contra Gabriel/Rufino, Ortiz de Zárate apoyó sin mucha convicción las denuncias contra el hijo, enrolado en la compañía miliciana del Valle.

51 Se dijo que Gabriel/Rufino vio un libro en donde se enseñaba al «protestante más rústico» a enfrentar al «teólogo más sutil», además de otros ejemplares similares que Antonio aseguró estaban en poder de Felipe, Don Felipe Barragán, vecino y mercader en el Valle del Maiz, por proposiciones, 1762, AHMCR, Fondo Diocesano, sección Justicia, siglo XVIII, exp. 60, caja 1238, ff. 42-43. También se mencionan los libros en Sobre las diligencias remitidas contra D. Felipe Barragán y D. Rufino Barragán su difunto padre, en razón de los libros que se dice fueron dados por un extranjero en el navio de D. Rufino y hoy paran en poder de D. Felipe, 1769, AGN, Inquisición, volumen 1042, exp. 37, f. 249. Lo cierto es que la segunda mitad del siglo XVIII vio un aumento en la cantidad de títulos y ejemplares de libros prohibidos en Nueva España. Medina, 1991: 460-472.

52 Para que cualquiera persona decente que sepa leer, y escribir, notifique al justicia del 
El justicia acusó, otra vez, a Felipe y a su padre de asesinos, sostuvo que el testamento del nativo de la Mancha era ilegal y, en consecuencia, embargó los bienes. Felipe denunció que el embargo era ilegal y el testamento de su padre legítimo, hecho ante escribano real en la capital virreinal. El abogado de Felipe apeló a su fuero militar, pues era un miliciano que servía al rey en la frontera. El virrey, marqués de Cruillas (1760-1766), como presidente de la Real Audiencia, le dio la razón ${ }^{53}$.

En cuanto a la acusación ante la Inquisición, pasaron tres años y la denuncia perdió fuerza, aunque se nombró al comisario del Santo Oficio para Santiago de los Valles, José Miguel Pereli, para que continuara las pesquisas ${ }^{54}$. Éste fue muy persistente, pero los denunciantes principales ya no estaban en el Valle: los franciscanos habían sido trasladados a conventos en el sur del obispado michoacano, Otero vivía en Irapuato y los Morales se habían ido también. Tampoco Antonio Miguel formalizó su denuncia, porque llegó a un entendimiento con su medio hermano ${ }^{55}$. Pereli se desesperó por la falta de resultados, pues nadie declaraba en contra del poderoso Felipe Barragán. Ni los arrieros que entraban al pueblo se atrevían a opinar contra él; sólo lo tenían «por usurero», por lo que fue imposible concretar la denuncia. Finalmente, los inquisidores en México decidieron archivar la investigación «interin no sobreviene mayor prueba» en octubre de $1771^{56}$.

Felipe Santiago sorteó esos peligrosos primeros años sin la presencia y protección de su padre, consolidándose «como es, el más poderoso de esta jurisdicción, los más del Valle del Maíz, penden de él por los efectos que les fía etc. Y de esta manera los tiene a su disposición». Gabriel/Rufino y sus vástagos no fueron hombres débiles o taimados. Felipe pertenecía a las milicias de frontera; no dudaba en matar a quien atentara contra sus intereses económicos y afrontaba los riesgos físicos, imitando así a su padre al conducir las recuas con los artículos de compraventa. Los Fernández Barragán representaban un

partido del Valle del Maíz, remita a esta capitanía general los autos que se expresan en el escrito inserto bajo la pena de quinientos pesos, 1762, AGN, General de parte, volumen 43, exp. 316, f. $198 \mathrm{v}$.

53 V. E. manda a don Antonio Fernández de Iragorri, proceda a sacar a don Manuel Pérez Correa comisionado del corregidor de la Villa de los Valles los 500 pesos de la multa, que en el antecedente despacho se le impuso, y en su defecto ejecute lo que se le previene entregando a don Felipe Santiago Barragán los bienes que le hubiere embargado el dicho Correa, 1762, AGN, General de parte, volumen 43, exp. 342, ff. 212v-216v.

54 Don Felipe Barragán, vecino y mercader en el Valle del Maíz, por proposiciones, 1762, AHMCR, Fondo Diocesano, sección Justicia, siglo XVIII, exp. 60, caja 1238, ff. 34-63.

55 Idem.

56 Idem. 
tipo de habitante de la frontera: individuos endurecidos por las dificultades del clima, por la escasez de casi todo, por la amenaza frecuente de los indios nómadas y por las rivalidades entre ellos. Antes del establecimiento del Nuevo Santander (1749), la frontera era inhóspita y pocos años después las cosas apenas habían mejorado. Pero también había sido el espacio de refugio donde vivir y prosperar a pesar de sus ideas heterodoxas. Durante las siguientes décadas, Felipe Barragán aprendió que el silencio y la prudencia eran excelentes compañeras y mejores ayudas mercantiles, pues se enriqueció como nadie más en la antigua frontera, hasta consolidarse como el comerciante más rico de la región:

gozaba bastante caudal, y en él las mismas posesiones, y aun más de las que cita el interrogatorio, con más un vasto comercio de géneros, compuesto de su tienda principal; otra al cargo de don José Antonio Chávez, en este Valle, una en la villa de Tula, a cargo de don Juan Gutiérrez, que después pasó al de don José Fernández y otra en Alaquines, al cargo del difunto don Tomás Osorio ${ }^{57}$.

\section{JOSÉ FLORENCIO Y LAS HERENCIAS BARRAGÁN}

En 1782, año de su segundo matrimonio, Felipe Barragán «prudentemente» estimó su capital en 200.000 pesos $^{58}$. Una fortuna «en bienes muebles, raíces, semovientes, y reales efectivos». Once años después, en 1793, en cierta información que recabó su hijo José Florencio, el español Francisco Miguel de Arcos aseguró que:

conoce a la persona de don Felipe Barragán. Que sabe es hombre de honor, buena conducta y honrados procedimientos, y que es cierto que el caudal de éste pasa de millón, de público y notorio, está libre de todo gravamen, y que antes si al dicho caudal le deben cantidades varios individuos ${ }^{59}$.

Aunque el dato del millón no sea seguro, no pesaban deudas ni obligaciones financieras sobre la fortuna de Felipe, antes bien, él era acreedor de varios individuos. Crió dos hijos con su primera esposa, Ana María de los Dolores Trejo y Sáenz: María Josefa de los Dolores y José Florencio Fernández del

57 Autos seguidos por los naturales del Valle del Maíz de la jurisdicción de Villa de Valles con los vecinos españoles y la casa mortuoria de don Felipe Barragán sobre tierras, 1800, AGN, Tierras, volumen 1325, exp. 1, f. 18v.

58 Testamento de Felipe Barragán, 1796, AGN, Tierras, volumen 1325, exp. 1, f. $138 \mathrm{r}-138 \mathrm{v}$.

59 Primera copia testimoniada, autorizada, y comprobada de la información del caudal que goza el capitán don José Florencio Barragán a que hace referencia, 1793, AGN, Vínculos y mayorazgos, volumen 282, exp. 2, s. n. f. 
Castillo Jáuregui y Barragán, Trejo y Sáenz. Ana María Trejo murió en 1778. Pasados cuatro años, Felipe Barragán se unió con María Faustina Ortiz de Zárate, hija del capitán José Antonio Ortiz de Zárate y de María Salvadora Andrada Moctezuma. El primogénito de Felipe Barragán, José Florencio, siguió en su juventud varios rumbos mientras encontraba un lugar dentro de la estructura social, y un oficio acorde con su gusto y su sentido de orgullo. Incluso hubo un tiempo en el que estuvo en malas relaciones con su padre:

Que en tiempo que estuvo fuera de la gracia de su padre don Felipe Barragán [...] le dijo el dicho don José Florencio, que no necesitaba de su padre, porque tenía conveniencia en Guanajuato, pues un hombre de caudal le había ofrecido que entraría de cajero mayor, por haberle dejado todo un día comerciando en su tienda, y haberle agradado su inteligencia en el comercio ${ }^{60}$.

El problema pudo deberse al hecho de que José Florencio se había casado con una indígena del Valle del Maíz ${ }^{61}$. Las uniones interraciales habían sido comunes en la frontera y no sólo en concubinato. Algunos de los españoles o criollos que buscaron el ascenso social se unieron a mujeres de la familia Aguilar, quienes conformaron una compañía miliciana propia, con privilegios reales y poder social ${ }^{62}$. Gabriel/Rufino tuvo predilección por las mujeres indígenas (aunque sin casarse), pero a Felipe Barragán no le hizo gracia el enlace de su hijo; descendiente de hidalgos y él mismo con pretensión de limpieza de sangre y de cristiano viejo, quería evitar mayores manchas en el expediente familiar. Una cosa eran los concubinatos de su juventud y otra muy diferente un matrimonio interracial. El joven José Florencio no pareció muy afectado por la ruptura, pues su padre le había dado lo que le correspondía de su herencia para que hiciera negocios: «y a uno y a otro [hijos] les tengo entregados por cuentas de sus legítimas a treinta mil pesos, de los que aun no me han otorgado recibo alguno» ${ }^{63}$. Con la fortuna heredada, puso un negocio en Rioverde donde «vive, y esta avecindado, y con tienda de ropas» ${ }^{64}$. En 1783, José Florencio hizo algo

60 Pretensión de don José Florencio Barragán vecino del Valle del Maíz en la provincia de Rioverde, para notario de este Santo oficio. Despreciada, 1783, AGN, Inquisición, volumen 1257, exp. 13, ff. 215-223.

61 Según el testamento de Felipe Barragán, de 1783, «don José Florencio Barragán, y Moctezuma, que ya es casado con Rita de Aguilar, india natural de dicho Valle del Maíz». Testamento de Felipe Barragán, 1796, AGN, Tierras, volumen 1325, exp. 1, f. 133.

62 Juan de Dios Andrada Moctezuma, el patriarca de esa familia, en su cuarto matrimonio se casó con la viuda de uno de ellos. Sobre la milicia de los Aguilar, Rangel, 2008: 111-114.

63 Testamento de Felipe Barragán, 1796, AGN, Tierras, volumen 1325, exp. 1, f. 133.

64 Pretensión de don José Florencio Barragán vecino del Valle del Maiz en la provincia de Rioverde, para notario de este Santo oficio. Despreciada, 1783, AGN, Inquisición, volumen 1257, exp. 13, ff. 218, 220v. 
inesperado: solicitó el nombramiento de notario del Santo Oficio para Rioverde. Los testigos entrevistados por el agente de la Inquisición dieron las más favorables referencias, así como el franciscano encargado de la custodia de Rioverde:

de vista y trato se ha portado con honra, temor a Dios, santo celo, buena loa y mejores costumbres, haciéndose amable a los ojos de todos [...] con aquel honor y esplendidez correspondiente a su buena crianza [...] y portándose en todo con arreglo, a la buena fama, costumbres y procederes, que corresponden a sus buenas operaciones, y que jamás a dado que decir, y que notar a su persona ${ }^{65}$.

Pero el tribunal rechazó su solicitud; tenía en su contra su matrimonio interracial, pero, sobre todo, el proceso contra su abuelo y la acusación contra su padre. ¿Qué esperaba el nieto de Gabriel/Rufino con este movimiento? José Florencio dijo que «servir a ambas Majestades», pero tal vez pensó que estar dentro del tribunal inquisitorial le serviría a él y a su familia para prevenir sus pesquisas, es decir, tener muy cerca a sus enemigos. Al no resultar el audaz intento, en 1787 decidió organizar una compañía miliciana en la villa de Santa Bárbara, en la colonia del Nuevo Santander, siguiendo las tradiciones de la frontera. Después, junto con su padre y sus tíos, se unió como oficial a las milicias reorganizadas por Félix Calleja en 1793 y $1794^{66}$.

Felipe Barragán murió en diciembre de 1796 en Valle del Maíz. Apenas lo enterraron, sus herederos comenzaron las negociaciones para dividir la enorme fortuna ${ }^{67}$. Ante la perspectiva de un pleito legal que podría consumir la herencia en años (o décadas) de tribunales y jueces, en octubre de 1797 los herederos pactaron hacer un reparto que conviniese a todos; quince meses después también arreglaron la división ordenada y pacífica de las haciendas. La división de la herencia repartió el poder económico en tres grandes ramas: Eyzcoa, Ortiz de Zárate y José Florencio. En 1799, y gracias a su amistad con Calleja, José Florencio fue propuesto para comandante de todas las compañías milicianas de la región.

Pero nada le impedía al jefe miliciano cuidar sus intereses mercantiles, por lo que viajaba bastante entre México, Querétaro, San Luis Potosí y Rioverde, como lo habían hecho su padre y su abuelo. Tales jornadas le permitían cono-

65 Idem.

66 Rangel, 2007: 53-77.

67 Convenio previo al juicio de sucesión testamentaria de los bienes de Felipe Barragán, 17 de octubre, Archivo Histórico del Estado de San Luis Potosí (AHSLP), Registro público de la propiedad y del comercio, Protocolos del escribano Silvestre Suárez, teniente del cabildo y de su teniente Antonio María Suárez, 1797, n. ${ }^{\circ} 108$. 
cer mucha gente, comerciantes o funcionarios locales, también médicos (a quienes buscaba por achaques y padecimientos) y personajes bizarros. Uno de esos individuos fue el médico Jean de Langouran. Este súbdito francés fue acusado y encarcelado por herejía en Centroamérica; en el proceso se le trasladó a las cárceles de la Inquisición en la ciudad de México, donde fue «reconciliado» en el auto de fe de agosto de 1795; se le acusó de hereje «formal y luterano», así como de «deísta y judaizante» ${ }^{68}$. En 1796 estaba recluido en el Colegio de la Santa Cruz en la ciudad de Querétaro.

En ese tiempo, José Florencio visitó la ciudad para entrevistarse con uno de sus corresponsales mercantiles. Según la versión que dio a la Inquisición, aprovechó su estancia para ver a un boticario que le recetaba varios medicamentos y éste le recomendó que viera a un médico francés muy bueno, aunque recluido en el convento franciscano. Como era de esperarse en un Barragán, no tuvo ningún prejuicio en entrevistarse con un hereje, y buscó ese mismo día a Langouran. De la entrevista, José Florencio sacó otra receta para sus achaques y una anécdota que contar a sus amigos. Pareció no darse cuenta de las diferentes percepciones sobre herejes franceses hasta que comentó la historieta en varias ocasiones: primero en una reunión en casa del coronel Silvestre del Portillo, en San Luis Potosí, y otra con el médico José Mascareña en la misma ciudad. El médico lo denunció ante el comisario del Santo Oficio en San Luis, el cura José Joaquín Flores de Valdés. Mascareña acusó a José Florencio de estar de acuerdo con Langouran en afirmaciones comprometedoras:

el cual médico, en la conversación le dijo: Que Jesucristo había en cierto modo, sido bien sentenciado por Pilatos, no atendidas las circunstancias de la persona de Cristo, sino el orden judicial, y que viniendo en estas circunstancias los padres del Colegio, le dijo el don Florencio a el médico, dice v. m. bien, pero el que declara, cuando se lo contó don Florencio, dice que le replicó que de ninguna manera había hecho bien Pilatos, por algunas razones que le dio, a lo que el don Florencio otorgó y convino. Asimismo declara, que le dijo don Florencio, que le había dicho que lo habían puesto en parte donde pasaba maltrato ${ }^{69}$.

68 Medina, 1991: 437. Báez-Camargo, 2008: 139. Langouran era originario de Burdeos. Tuvo una vida azarosa y pintoresca antes de caer en manos de la Inquisición.

69 Diligencias seguidas en S. Luis Potosí con motivo de las declaraciones de D. José Mascareñas Médico de profesión y vecino de la ciudad de San Luis Potosí, así como las de D. José Florencio Barragán, comerciante, capitán de la sexta compañia de Frontera del nuevo Santander, vecino del pueblo de Rioverde y residente en el Valle del Maíz, sobre una conversación que con motivo de consulta médica se originó entre D. Juan Langouran, francés, médico, preso en el convento de la Santa Cruz de Querétaro, y los deponentes, San Luis Potosí, 1798, AGN, Inquisición, volumen 1320, exp. 3, f. 291r-291v. (Subrayado en el original). Flores de Valdés era cura y juez eclesiástico de la parroquia de San Sebastián. 
Según Mascareña, el capitán Barragán también estuvo de acuerdo en que el proceso y la sentencia contra Langouran eran injustos, además de afirmar que le habían quitado ocho mil pesos al francés. Así, gracias a su indiscreción, parecía que el peligroso pasado de los Barragán regresaba intempestivamente. Fray José Antonio Borja, comisario delegado de la Inquisición en Valle del Maíz, tomó declaración a José Florencio. En el interrogatorio, realizado en febrero de 1798, Barragán reconoció haber visto al francés en busca de una receta médica más eficaz para sus padecimientos. En su versión, éste le dijo que la receta de píldoras de cicuta era nociva por sus efectos, el comerciante y capitán de milicias le respondió varias veces: «es verdad, dice v. m. muy bien $»^{70}$. Barragán aseguró que la afirmación sobre el juicio de Jesucristo la había escuchado de unos desconocidos en otra ocasión, y no en su visita al francés. ¿Quizás la había escuchado de su padre o de su abuelo? En este punto, el historiador solo puede conjeturar.

El asunto, finalmente, no tuvo mayores consecuencias. Flores de Valdés desestimó el proceso aduciendo «que siendo don Florencio Barragán mozo, y con mucho dinero, me imagino (según lo poco que lo he tratado) que hablaría con desembarazo, y con poca refleja». Es cierto lo de su falta de sensatez, y tal vez también lo de su inexperiencia, pero es demasiada coincidencia que buscara un médico extranjero, hereje, con opiniones similares a las de su padre. En esos días había una psicosis entre los funcionarios virreinales, civiles y eclesiásticos contra los franceses debido a los acontecimientos en Europa ${ }^{71}$, que debía ser compartida por amplios sectores de la sociedad novohispana. No era prudente hablar con gabachos, mucho menos si eran reos de la Inquisición. Por otro lado, si las frases sobre el juicio de Jesucristo eran de ocasiones anteriores, entonces delatan una propensión de Barragán por tener conversaciones al filo de la heterodoxia, como sus antecesores.

José Florencio no salió indemne del asunto, porque sentó un precedente en su expediente como comandante miliciano. Para tratar de conservar intacto su honor personal, envió un escrito a la Inquisición en México por considerar que

70 Idem. Subrayado en el original.

71 Medina, 1991: 427-439. Pérez-Merchand, 2005: 116-118. El mismo José Florencio sabía del escándalo por varios franceses presos por la Inquisición, Diligencias seguidas en $S$. Luis Potosí con motivo de las declaraciones de D. José Mascareñas Médico de profesión y vecino de la ciudad de San Luis Potosí, así como las de D. José Florencio Barragán, comerciante, capitán de la sexta compañía de Frontera del nuevo Santander, vecino del pueblo de Rioverde y residente en el Valle del Maiz, sobre una conversación que con motivo de consulta médica se originó entre D. Juan Langouran, francés, médico, preso en el convento de la Santa Cruz de Querétaro, y los deponentes, San Luis Potosí, 1798, AGN, Inquisición, volumen 1320, exp. 3, ff. 290, 297. 
las pesquisas contra su persona eran un acto de difamación contra su catolicis$\mathrm{mo}^{72}$. Pero el precedente permaneció a pesar de sus reclamos. En el ámbito político general del virreinato, las cosas no estaban tranquilas: la Corona estaba comprometida en las guerras europeas. El hecho de que un jefe miliciano y líder regional se involucrara en un asunto sospechoso no podía pasar desapercibido. Aunque no hay mayores pistas sobre el asunto, seguramente el apoyo de su red de socios de negocios, en especial en la ciudad de México, evitaron mayores presiones sobre José Florencio. Por lo pronto, se retrasó su ascenso a la comandancia de las milicias de frontera hasta $1803^{73}$.

Entre 1803 y 1808, José Florencio parecía intocable: comandante miliciano de toda la región, uno de los comerciantes más ricos y un hombre con excelentes conexiones a nivel virreinal; lo mejor de las herencias familiares parecían consolidarse en su persona. Sin embargo, en el cenit de su hegemonía regional resurgieron las denuncias en su contra. En 1808 fue acusado de supuestas murmuraciones de tipo político. El fraile de la misión de la Divina Pastora, Bernardo de Oca, aseguró haber escuchado del comandante que «de España no se sabía desde enero, que todo era falso que Bonaparte era muy vivo que de todo tenía la culpa Fernando Séptimo por las desavenencias con su padre. Y contra lo que se expresó más fue sobre los voluntarios de Fernando que para que era tanta multitud sin jefe ni cabeza determinada» ${ }^{74}$. El custodio franciscano Isidro Carranza recomendó a Oca delatar a Barragán puesto que, en su opinión, eran expresiones «denunciables [...] por las circunstancias críticas del día, y que en todo caso a vuestra excelencia [el virrey] pertenecía graduar el mérito de semejantes dichos, y a nosotros avisar» ${ }^{75}$. El asunto se complicó cuando José Florencio se enteró. Los religiosos temieron las consecuencias, «teniendo por enemigo a un hombre poderoso, como lo es el caballe-

72 Escrito del capitán de milicias del resguardo de la colonia del Nuevo Santander, del comercio del pueblo de Rioverde, por considerarse difamado en su catolicismo, año 1798, AGN, Inquisición, volumen 730, ff. 209-211.

73 Además, en 1801, José Florencio fue denunciado por una supuesta conspiración independentista, en la cual él era el principal organizador. Rangel, 2008: 272-274.

74 Documentos relativos a la acusación hecha contra don Florencio Barragán, teniente coronel, por murmuraciones en San Luis Potosí, 1808, AGN, Indiferente de Guerra, volumen 188b. Los voluntarios de Fernando VII fueron milicias formadas a raíz de las noticias sobre su prisión por los franceses. Archer, 1983: 359-360. La conversación entre el fraile y José Florencio Barragán ocurrió cuando éste estaba de paso por Querétaro y rumbo a Valle del Maíz.

75 Documentos relativos a la acusación hecha contra don Florencio Barragán, teniente coronel, por murmuraciones en San Luis Potosí, 1808, AGN, Indiferente de Guerra, volumen $188 \mathrm{~b}$. 
ro don Florencio y de unos respetos y conexiones temibles en todas circunstancias».

En la ciudad de México, las autoridades tomaron las cosas con calma. Había pasado poco tiempo del golpe de estado contra José de Iturrigaray y el nuevo virrey, Pedro Garibay, no parecía deseoso de agitar más el ambiente político en Nueva España, en un contexto enrarecido por los rumores sobre movimientos independentistas ${ }^{76}$. Así que el asunto se manejó sin mayor alboroto: el fiscal de lo civil aconsejó que se desechara la acusación por falta de sustancia. Mediante un oficio reservado, de 1809, el virrey llamó la atención a José Florencio para que fuera más prudente:

Las expresiones que v. m. vierte sobre la astucia y viveza del traidor Bonaparte, y estado de la Península, que atribuye a culpa de N. inocente y amado soberano el señor don Fernando $7 .^{\circ}$, por las desavenencias con su augusto padre, nunca son bien sonantes, aunque supongo, que v. m. las profiere sin fines siniestros y torcidos; más para evitar la imprecisión que acaso puedan hacer en algunos incautos por las interpretaciones que admiten, capaces en las circunstancias de inducir conceptos contrarios a la quietud, prevengo a v. m. omita dichas conversaciones en el concepto de que será muy de mi desagrado, que vuelvan a llegar a mi noticia semejantes producciones $^{77}$.

La conjunción de poder militar, económico y político en José Florencio ponía nerviosos a muchos y le granjeaban múltiples enemigos tanto en la región como en los círculos de la intendencia potosina y aun en la ciudad de México. Una denuncia por traición o infidencia, cierta o falsa, podía dañar seriamente su posición. Una década atrás, quizás la inquisición le había dejado ir, en parte por la propia ineptitud institucional y en parte por su red de amistades, pero en el ambiente político-militar de 1808 las opiniones fuera de lugar podían ser muy costosas, sobre todo si era un acertado análisis de la política peninsular y virreinal. En este contexto, el mensaje del virrey fue claro, no se le volvería a tolerar una opinión semejante. José Florencio expresó ser un fiel vasallo en una misiva al virrey:

como [f. s. n.] como encarecidamente se lo ruego por el sagrado nombre de nuestro augusto Rey y Señor Fernando $7 .^{\circ}$ que Dios prospere en el trono de sus mayores, a donde se nos restituya, pues solo esta satisfacción podrá restituir la tranquilidad del espíritu de un vasallo leal como yo, que se advierte vilipendiado, sin el honor y reputación que ha procurado conservar sobre aquel sólido principio [...] A este solo laudable fin se contrae mi ruego, que [...] se aclare la falsedad con que se me ha

76 Archer, 1983: 351-375. Hamnet, 1997: 104-108.

77 Documentos relativos a la acusación hecha contra don Florencio Barragán, teniente coronel, por murmuraciones en San Luis Potosí, año 1808, AGN, Indiferente de Guerra, volumen $188 \mathrm{~b}$. 
acusado, y la verdad de los justos sentimientos de que estoy poseído, siendo un fiel servidor de mi Rey ${ }^{78}$.

José Florencio salió bien librado, pero si quería, al igual que diez años atrás, ser resarcido en su honor, se le permitió ofrecer un donativo en «proporción con el concepto que generalmente se tiene de su grandes facultades, pues este es el mejor medio de indemnizarse y de presentar a la Nación y al Soberano un testimonio irrefragable de su amor y patriotismo». A los franciscanos, en cambio, se les recomendó alejarse de Rioverde lo más pronto posible y por el tiempo suficiente para que las cosas se calmaran.

En julio de 1810, José Florencio fue elegido diputado a las Cortes de Cádiz por la provincia de San Luis Potosí7 ${ }^{79}$. Era la culminación de su vida personal y la transformación de su carrera miliciana y su poder económico en un cargo relevante, en los momentos de máxima efervescencia política. En ese año había solicitado el grado de coronel de milicias. Pero murió sin embarcarse a la península, justo antes de comenzar la guerra de la independencia ${ }^{80}$.

\section{CONCLUSIONES}

Los Fernández Barragán constituyen un caso familiar extraordinario. De la profesión de bandido de Gabriel/Rufino, que lo colocó en el mundo criminal, a su afición por las relaciones ilícitas y por las opiniones religiosas heréticas, el fundador de la dinastía fue un escandaloso ejemplo de lo que un hidalgo podía llegar a ser en el mundo novohispano. Sus opiniones e ideas heréticas lo destacan de entre sus contemporáneos; los concubinatos y los robos formaban parte de la vida «normal», solo que en su aspecto ilícito, pero la herejía colocaba al individuo al filo de lo terreno y de lo divino. Gabriel/Rufino fue un hereje según los vecinos de Valle del Maíz y según la Inquisición, es decir, lo era de acuerdo con lo establecido por la religión católica dominante. Protestante o «libertino», su herejía era abrigar opiniones radicales y considerar a la religión como una invención humana. La frontera y el anonimato encubrieron a Gabriel/Rufino hasta cierto límite, pero la frontera se desplazaba hacia el norte a mediados del siglo XVIII, y el anonimato se perdió en cuanto chismes y rumo-

78 Idem.

79 Sobre elección del teniente coronel Bernardo Villamil como diputado a Cortes por San Luis Potosí, por muerte de José Florencio Barragán, año 1810-1812, AGN, Indiferente virreinal, caja 2764, sección ayuntamientos, exp. 002, ff. 48-52v.

80 Sobre su muerte, ver Sobre elección del teniente coronel Bernardo Villamil como diputado a Cortes por San Luis Potosí, por muerte de José Florencio Barragán, año 1810-1812, AGN, Indiferente virreinal, caja 2764, sección ayuntamientos, exp. 002, ff. 21-24v. 
res llegaron a oídos de la Inquisición. Su muerte fue el escape más conveniente para el viejo hidalgo.

Su hijo Felipe cambió su estrategia personal de sobrevivencia porque la Inquisición y la sociedad local buscaban atraparlo en las expresiones heterodoxas que acostumbraban él y su padre. Debió usar de todo el poder coercitivo que su dinero y su violencia le daban porque los Barragán eran tan odiados como temidos por sus vecinos. Pasado el vendaval, decidió que valía más una boca cerrada que mil testigos favorables, y entonces su comportamiento y opiniones públicas se volvieron aceptables, ortodoxas. La prudencia y las creencias encubiertas son rasgos comunes entre disidentes acusados y persegui$\operatorname{dos}^{81}$, y muestran el éxito de la Inquisición en controlar las expresiones heterodoxas. Sin embargo, el breve momento en que expuso sus opiniones permite atisbar el estrato profundo de las ideas familiares sobre cuestiones teológicas, que rayaban en el protestantismo y en lo que se ha dado en llamar «libertinaje». Claro que el problema de las herejías es que aparecen filtradas por las miradas e interpretaciones de los inquisidores y de los denunciantes que, escandalizados, no aciertan a distinguir sutilezas teológicas o filosóficas, o no quieren hacerlo. El caso de José Florencio es paradójico. Cimentado en la sólida posición de su padre, y enseñado en la prudencia y discreción que le permitieron prosperar, su vida estuvo salpicada una y otra vez por las sospechas sobre sus opiniones. Lo que cambia con él es el ámbito de interés en que se mueve, pues añade a la herejía la disidencia: era un miliciano de ideas propias que critica abiertamente al rey en una época en que era muy peligroso hacerlo.

Queda la pregunta de cuál fue la razón que llevó a José Florencio a conversar con Langouran, ¿por su origen francés? Este encuentro se realizó en una época en que los franceses representaban la vanguardia ideológica, filosófica y política. ¿O se dirigió a él porque era protestante? Alguien con quien conversar de temas conocidos pero adormecidos en la discreción que permite sobrevivir. Quizás fueron ambas cosas y otras más que apenas se pueden sospechar. Cierto que las denuncias contra los Barragán fueron hechas por sus enemigos, desplazados o amenazados por la prosperidad económica del comerciante, celosos del fulgurante éxito de un don nadie. Pero la homogeneidad de las creencias en los tres Barragán, en un periodo de cuatro décadas, indica un sustrato ideológico compartido, familiar, íntimo, que floreció en las favorables condiciones de una frontera y una prosperidad económica acompañada de poder político y social.

\footnotetext{
81 Tenenti, 1999: 244.
} 


\section{BIBLIOGRAFÍA}

Aguirre, Carlos y Walker, Charles, Bandoleros, abigeos y montoneros. Criminalidady violencia en el Perú, siglos XVII-XIX, Lima, Instituto de Apoyo Agrario, 1990.

Alberro, Solange, «El amancebamiento en los siglos XVI y XVII: un medio eventual de medrar», Antonio Guzmán y Lourdes Martínez (eds.), Familia y Poder en Nueva España: Memoria del tercer simposio/Seminario de historia de las mentalidades, México, Instituto Nacional de Antropología e Historia, 1991: 155-166.

Amerlinck, Mari-Jose, From Hacienda to Ejido: The San Diego de Rioverde Case (facsímil de tesis de doctorado), Michigan, University Microfilms International, 1980.

Archer, Christon, El ejército en el México borbónico (1760 -1810), México, Fondo de Cultura Económica, 1983.

Báez-Camargo, Gonzalo, Protestantes enjuiciados por la Inquisición en Iberoamérica, Puebla, Cajica, 2008.

Bazant, Jan, Cinco haciendas mexicanas. Tres siglos de vida rural en San Luis Potosí, México, El Colegio de México, 1980.

Borah, Woodrow y Cook, Sherburne, «Marriage and Legitimacy in Mexican Culture: Mexico and California», California Law Review, 54/2 (Berkeley, California, 1966): 946-1008.

Brading, David, Una Iglesia asediada: el obispado de Michoacán, 1749-1810, México, Fondo de Cultura Económica, 1994.

Brading, David, Mineros y comerciantes en el México borbónico (1763-1810), México, Fondo de Cultura Económica, 1995.

Cabrera, Matilde, Cuatro grandes dinastías mexicanas en los descendientes de los hermanos Fernández de Lima y Barragán, San Luis Potosí, s. e, 1956.

Céspedes del Castillo, Guillermo, América Hispánica, 1492-1898, Barcelona, Labor, 1983.

Diccionario de autoridades, vol. 3. Edición facsímil de la editada por la Real Academia de la Lengua, Madrid, Gredos, 1969 [1732].

Dysart, Jane, «Mexican Women in San Antonio, 1830 -1860», The Western Historical Quarterly, 7/4 (Logan U., 1976): 365-375.

Domínguez Ortiz, Antonio, «Precedentes del bandolerismo andaluz», Juan Antonio Martínez Comeche (ed.), El bandolero y su imagen en el Siglo de Oro, Madrid, Casa de Velázquez-Universidad Autónoma de Madrid, 1989: 21-29.

García Cárcel, Ricardo, «Presentación», Antonio Fernández Luzón y Doris Moreno (eds.), Protestantes, visionarios, profetas y místicos. Herejes, Barcelona, Random House Mondadori de Bolsillo, 2005: 9-21. 
González, Manuel, «La repoblación de Andalucía (siglos XIII-XV)», Relaciones, XVIII/69 (Zamora, 1997): 21-40.

Guillaume-Alonso, Araceli, «Le brigand castillan du siècle d'or vu a travers les archives des Santas Hermandades viejas: essai de typologie», Juan Antonio Martínez Comeche (ed.), El bandolero y su imagen en el Siglo de Oro. Madrid, Casa de Velázquez-Universidad Autónoma de Madrid, 1989: 11-20.

Hamnett, Brian, «Absolutismo ilustrado y crisis multidimensional en el periodo colonial tardío, 1760-1808», Josefina Zoraida Vázquez (coord.), Interpretaciones del siglo XVIII mexicano. El impacto de las reformas borbónicas, México, Nueva Imagen, 1992: 67-108.

Hobsbawn, Eric, Bandidos, Barcelona, Ariel, 1976.

Lockhart, James y Schwartz, Stuart B., América Latina en la Edad Moderna. Una historia de la América española y el Brasil coloniales, Madrid, Akal, 1992.

Lucena, Manuel, «El reformismo de frontera», Agustín Guimerá (ed.), El reformismo borbónico, Madrid, Alianza Universidad, 1996: 265-276.

McCaa, Robert, «Tratos nupciales: la constitución de uniones formales e informales en México y España, 1500-1900», Pilar Gonzalbo y Cecilia Rabell (coords.), Familia y vida privada en la historia de Iberoamérica. Seminario de historia de la familia, México, El Colegio de México-Universidad Nacional Autónoma de México, 1996: 21-57.

Medina, José Toribio, Historia del Tribunal del Santo Oficio de la Inquisición en México, México, Consejo Nacional para la Cultura y las Artes, 1991.

Menéndez Pelayo, Marcelino, Historia de los heterodoxos españoles, Obras completas de Menéndez Pelayo, vol. 5, Buenos Aires, Espasa-Calpe, 1951.

Montejarano, Rafael, El Valle del Maíz, San Luis Potosí, San Luis Potosí, Archivo Histórico de San Luis Potosí, 1989.

Penyak, Lee, Criminal Sexuality in central Mexico, 1750-1850 (facsímil de tesis de doctorado), Michigan, University Microfilms International, 1993.

Pérez-Merchand, Monelisa, Dos etapas ideológicas del siglo XVIII en México a través de los papeles de la Inquisición, México, El Colegio de México, 2005.

Péron, Mylène, «Dos visitas episcopales del siglo XVII en la Sierra de Nayarit. Intereses en juego y límites de la conquista espiritual del occidente mexicano», Relaciones, XVIII/69 (Zamora, 1997): 43-76.

Petit, Jacques-Guy, «Los marginales en el centro de la historia: pobres y prisioneros en Francia y Europa (siglo XVIII-principios del siglo XX)», Ángel Vaca Lorenzo (ed.), Disidentes, heterodoxos y marginados en la historia, Salamanca, Ediciones Universidad de Salamanca, 1998: 269-280. 
Powell, Philip, Capitán mestizo: Miguel Caldera y la frontera norteña. La pacificación de los chichimecas (1548-1597), México, Fondo de Cultura Económica, 1997.

Rangel, José Alfredo, «Linaje y fortuna en una zona de frontera. Felipe Barragán y su familia, 1713-1810», Estudios de Historia Novohispana, 37 (México, 2007): 123-166.

Rangel, José Alfredo, «Milicias en el oriente de San Luis Potosí, 1793-1813», Manuel Chust y Juan Marchena (eds.), Las armas de la nación. Independencia y ciudadanía en Hispanoamérica (1750-1850), Madrid, Iberoamericana-Vervuert, 2007: 53-77.

Rangel, José Alfredo, Capitanes a guerra, linajes de frontera. Ascenso y consolidación de las élites en el oriente de San Luis, 1617-1823, México, El Colegio de México, 2008.

Ratcliffe, Marjorie, «Adulteresses, Mistresses and Prostitutes: Extramarital relationships in Medieval Castile», Hispania, 67/3 (Walled Lake Mi., 1984): 346-350.

Shadow, Robert, Tierra, trabajo y ganado en la región norte de Jalisco, Zamora, El Colegio de Michoacán-Universidad de Guadalajara, 2002.

Slatta, Richard, «Introduction», Richard Slatta (ed.), Bandidos. The Varieties of Latin American Banditry, New York, Greenwood Press, 1987: i-viii.

Stern, Peter, «Marginals and Acculturation in Frontier Society», Robert Jackson (ed.), New Views of Borderlands History, Albuquerque, University of New Mexico Press, 1998: 157-188.

Tenenti, A., «Libertinaje y herejía a mediados del siglo XVI y comienzos del XVII», Jacques Le Goff (comp.), Herejías y sociedades en la Europa preindustrial, siglos XI-XVIII, México, Siglo XXI-Ministerio de Educación y Ciencia, 1999: 231-245.

Valdés, Carlos Manuel, Aux marges de l'empire: Societé et delinquance à Saltillo à l'époque coloniale, Perpignan, Université de Perpignan, 1995.

Vanderwood, Paul, «Nineteenth-Century Mexico's Profiteering Bandits», Richard Slatta (ed.), Bandidos. The Varieties of Latin American Banditry, New York, Greenwood Press, 1987: 13-26.

Velázquez, María del Carmen, Colotlán: doble frontera contra los bárbaros, México, Universidad Nacional Autónoma de México, 1961.

Weber, David, «Turner, los boltonianos y las tierras de frontera», Francisco de Solano y Salvador Bernabeu (coords.), Estudios (Nuevos y Viejos) sobre la frontera, Madrid, Consejo Superior de Investigaciones Científicas, 1991: 61-84.

Weber, David, La frontera española en América del Norte, México, Fondo de Cultura Económica, 2000.

Recibido el 22 de septiembre de 2009

Aprobado el 19 de noviembre de 2009 


\section{HERESIES AND DISSENT IN THE FRONTIER OF RIOVERDE: THE BARRAGÁN FAMILY IN THE $18^{\text {th }}$ CENTURY}

Thanks to knowledge acquired as a bandit and mule driver, the Spaniard, Gabriel Fernández de Lima, alias Rufino Barragán, amassed a great fortune after settling in Rioverde, a war zone populated since the end of the $17^{\text {th }}$ century by Spanish minor noblemen. His heretical opinions and dissolute lifestyle were scrutinised by the Inquisition, who also had problems with his son and grandson. The documentation gathered together in different archives allows us to reconstruct the lives of the members of this singular family of pioneers in the North, known for their rather unorthodox behaviour.

KeY words: Frontier, elites, trade, heresies, Septentrión Novohispano (Northern New Spain). 